Cahiers $d u$ MONDE RUSSE

\section{Cahiers du monde russe}

Russie - Empire russe - Union soviétique et États indépendants

54/3-4 | 2013

L'expérience soviétique à son apogée - Culture et société des années Brežnev / Volume II

\title{
The spirit of late socialism and the value of transformation
}

Brezhnevism through the lens of post-Soviet religious revival

L'esprit du "socialisme développé " et la valeur de la transformation : le

brejnévisme dans l'optique du renouveau religieux postsoviétique

\section{Sonja Luehrmann}

\section{(2) OpenEdition}

1 Journals

\section{Electronic version}

URL: https://journals.openedition.org/monderusse/7967

DOI: 10.4000/monderusse. 7967

ISSN: $1777-5388$

\section{Publisher}

Éditions de l'EHESS

\section{Printed version}

Date of publication: 1 July 2013

Number of pages: $543-563$

ISBN: 9782713224393

ISSN: $1252-6576$

\section{Electronic reference}

Sonja Luehrmann, "The spirit of late socialism and the value of transformation", Cahiers du monde russe [Online], 54/3-4 | 2013, Online since 01 July 2016, connection on 03 September 2022. URL: http://journals.openedition.org/monderusse/7967 ; DOl: https://doi.org/10.4000/monderusse.7967 


\title{
THE SPIRIT OF LATE SOCIALISM AND THE VALUE OF TRANSFORMATION
}

\author{
Brezhnevism through the lens \\ of post-Soviet religious revival
}

"The time of Brezhnev, time of our childhood, was not as closed as they say now. We had access to many different kinds of ideas, watched [the film] Andrei Rublëv and read whatever we wanted." These were the words of an interviewee, born in 1959, who reflected on the path that led her to be an editor and text designer in the publishing department of the Russian Orthodox Diocese of Ioshkar-Ola and Marii El, coterminous with one of the autonomous republics of Russia's Volga region. When I interviewed her in the spring of 2005, she was in her mid-forties, dyed her short hair purple, and greeted me in her office in the diocesan center in a business-like attire with skirt and jacket. A graduate of the philological faculty of the local teachers' college with additional training in computer graphics, she had shifted to work for the church two years previously after losing her job at a youth journal following a change in the journal's management. She openly admitted that her initial motivation for turning to work for the church was economic, but described a slow process of habituation to the ritual life of the church whose outcome was surprising to herself.

The editor had appeared for an initial meeting with the local bishop in trousers, and was only slowly "imbibing" Orthodox Christianity. Vladyka (the term of address for a bishop or other hierarch in the Russian Orthodox Church, from the Church Slavonic for "Lord") had a talent for finding "cast-aways" (zabroshennye liudi) who brought necessary skills, and did not try to rush her own "spiritual development." After two years in church employment, she still found it impossible to attend services regularly: "I have a hard time enduring the rigid rituals (zhëstkaia obriadnost')." Asked about differences between working in church publishing as opposed to a secular newspaper, she focused on gendered interactions: "here I work 
mainly with priests (batiushki), and they have more dignity than men in the secular media. They don't curse, don't drink, don't smoke." On the other hand, she often found it difficult to maintain the "feminine humility" (zhenskaia krotost') demanded of her in the new setting. But she still concluded that "the Lord brought me to this work" and, in spite of her secular upbringing as the daughter of a history teacher, created narrative continuity by looking back to her birth: "I was born on Saint Peter [and Paul]'s day, and my grandmother always said, what a bright holiday."

A path away from training in secular education and culture toward work for a religious organization was not rare for a member of the generation whose childhood and youth was spent under the rule of Leonid Brezhnev. At the same time as economic and political restructuring made public sector employment uncertain and often unpaid in the 1990s and early 2000s, religious organizations were expanding their scope of activities from liturgical services and life-cycle rituals to education and social outreach. Some teachers, journalists, and cultural workers found that putting their skills to the service of religious revival offered better pay, more respect, and better or at least more fulfilling working conditions. ${ }^{2}$ During ethnographic and archival research conducted in the Republic of Marii El between 2003 and 2008, I met many such cultural workers, for whom working for or collaborating with religious institutions was a way to make their lives more meaningful and have access to more resources. ${ }^{3}$

In this article, I take the reminiscences of these provincial converts as a starting point for an inquiry into the values and practices of their childhood and youth. Whereas some of the emerging historiography on the Brezhnev era treats it as a

1. All interviews and field observations cited in this article were conducted in Marii El in May-June 2003 and February 2005 - February 2006. To protect the privacy of my interlocutors while respecting the distaste for pseudonyms expressed by some of them, I identify them by a professional or confessional label rather than by name.

2. On the precarious positions of members of the post-Soviet intelligentsia, see Jennifer Patico, Consumption and Social Change in a Post-Soviet Middle Class (Stanford: Stanford University Press, 2008); Anne White, "Social Change in Provincial Russia: The Intelligentsia in a Raion Centre", Europe-Asia Studies 52, 4 (2000): 677-694; Agata Ładykowska, "Post-Soviet Orthodoxy in the Making: Strategies for Continuity Thinking among Russian Middle-Aged School Teachers," in Jarett Zigon, ed., Multiple Moralities and Religions in Post-Soviet Russia (New York: Berghahn, 2011), 27-47. On the work of religious organizations to expand the scope of their activities see Melissa Caldwell, "The Russian Orthodox Church, the Provision of Social Welfare, and Changing Ethics of Benevolence," in Chris Hann and Hermann Goltz, eds, Eastern Christians in Anthropological Perspective (Berkeley, Los Angeles: University of California Press, 2010), 329-350; P.B. Chuprikov, ed., Religii Rossii: problemy sotsial'nogo sluzheniia [Religions of Russia: Problems of Social Service] (M., Nizhnii Novgorod: Medina, 2011); Jarett Zigon, HIV is God's Blessing: Rehabilitating Morality in Neoliberal Russia (Berkeley, Los Angeles: University of California Press, 2011).

3. Marii El (known as Mari ASSR before 1991) is an autonomous republic of about 750,000 people, straddling the Volga River approximately $800 \mathrm{~km}$ east of Moscow. Religious traditions represented in the republic include the indigenous Mari religion practiced by some members of the titular nationality, Sunni Islam, Orthodox Christianity, and, more recently, a variety of Protestant Christian groups. Sonja Luehrmann, "Recycling Cultural Construction: Desecularisation in Postsoviet Mari El," Religion, State and Society 33, 1 (2005): 35-56; Luehrmann, Secularism Soviet Style: Teaching Atheism and Religion in a Volga Republic (Bloomington: Indiana University Press, 2011). 
time of quiet religious searching that led to the more public religious revival that began during late perestroika, I understand the journal editor's reference to "openness" in a slightly different way. Through the lens of archival sources on the cultural institutions and networks of political education that had shaped the views and habits of many of my interviewees, the Brezhnev era does not primarily appear as a time of religious revival. Rather, it was a time when a contradiction internal to Soviet ideological discourse - between homage to revolutionary change and commitment to stable state structures - led to an impasse. While constantly hearing about the value of transformation and newness, Soviet citizens from the late 1960s to the mid-1980s lived in a predictable social world where change was understood almost exclusively in terms of economic growth. For post-Soviet religious converts, I argue, this learned commitment to transformation is a more important legacy of their Brezhnev-era youths than any direct experience of illicit religious practice.

When considering the turn of former Soviet citizens to religion, some scholars emphasize the 1990s as a breaking point. They point to the economic and political uncertainty of the early 1990s, as well as the changing media representations of established religious institutions, as factors that drove people of various age groups and occupations to seek meaning and social support in ancestral or new religions. ${ }^{4}$ Others look back further and claim that the religious activity of the 1990s was a continuation of processes that began during the last decades of the Soviet Union. In what follows, I investigate the claim that there was a religious revival under Brezhnev to argue that there is limited evidence of such a phenomenon outside of intelligentsia circles in urban centers. Rather, the period was characterized by a relaxation of ideological vigilance with regard to a variety of non-Marxist narratives about national history and values, which were made attractive by the growing atrophy of official political discourse. For some people who came of age during the period now known as Stagnation, exploration of such alternative narratives eventually led to religious practice. The widespread use of the terms "spiritual values" and "spiritual growth" in documents from the period provides an example of a secular discourse about human potentials that may have inspired some people to extend their searches for personal and social transformation into engagement with non-human forces.

Methodologically, I am inspired by the ethnohistorical and ethnoarcheological idea of "upstreaming": starting in an observable present and using it as a source of clues and relevant questions for interpreting historical records. ${ }^{5}$ Whereas for

4. Alexander Agadjanian, "The Search for Privacy and the Return of a Grand Narrative: Religion in a Post-Communist Society," Social Compass, 53, (2006): 169-184; Mathijs Pelkmans, "Introduction: Post-Soviet Space and the Unexpected Turns of Religious Life," in M. Pelkmans, ed., Conversion after Socialism: Disruptions, Modernism and Technologies of Faith in the Former Soviet Union (New York: Berghahn, 2009) 1-16.

5. William Sturtevant, "Anthropology, History, and Ethnohistory," Ethnohistory, 13, 1-2 (1966): 1-51; Michael K. Foster, "On Who Spoke First at Iroquois-White Councils: An Exercise in the Method of Upstreaming," in Michael Foster, Jack Campisi, and Marianne Mithan, eds., Extending the Rafters: Interdisciplinary Approaches to Iroquoian Studies (Albany: State University of New York Press, 1984), 183-207. 
historians this may sound like dangerous presentism, ${ }^{6}$ I would argue that debates about the beginning of religious revival on the territory of the former Soviet Union necessarily involve looking at historical evidence from a perspective that is colored by the observation of present social trends. For example, scholars who argue that the history of state-imposed atheism and religious resurgence in the former Soviet Union demonstrates that people are naturally religious often focus on evidence of the continuous strength of religiosity throughout the Soviet period. ${ }^{7}$ By contrast, scholars who wish to emphasize the contingent and (re-)invented character of many post-Soviet religious phenomena tend to find a more robust presence of atheism especially among the postwar Soviet generations, who grew up in a society in which access to religious institutions had been severely curtailed. ${ }^{8}$

More generally, empirical research on the final decades of the Soviet Union was pioneered by anthropologists and other social scientists with an explicit interest in moving "upstream" from post-socialist developments and constructing their genealogy. A prominent example is Alexei Yurchak's work on the "last Soviet generation," based on letters and journals contributed by people born between the 1950s and early 1970s and motivated by the question why people who grew up under a supposedly "stagnant" system often adapted quite readily to the changes of perestroika and emerging capitalism. ${ }^{9}$ As archival collections ranging from the late 1960 s to the early 1980 s become accessible to historians, they can correct some of the images of those years constructed by social scientists. Historians, for instance, might be skeptical of Yurchak's tendency to lump all of Soviet history after 1950 together as the time after "Stalin's uncanny paradigm shift"10 from a society controlled by ideology as interpreted by an authoritative leader to a realm of performativity where correct behavior was more important than ideological agreement. Archives-based studies on the 1950s, 60s, and 70s are much more careful to unearth differences as well as similarities between these decades, as the Soviet Union went through several changes in leadership and economic climate, and was exposed to different forms of international influence. ${ }^{11}$

6. James Axtell, “Ethnohistory: An Historian's Viewpoint,” Ethnohistory, 26, 1 (1979): 1-13.

7. Paul Froese, The Plot to Kill God: Findings from the Soviet Experiment in Secularization (Berkeley: University of California Press, 2008).

8. Jeanne Kormina and Sergei Shtyrkov, "St. Xenia as a Patron of Female Social Suffering: An Essay on Anthropological Hagiology," in Zigon, ed., Multiple Moralities, 168-190; Luehrmann, Secularism Soviet Style.

9. Alexei Yurchak, Everything Was Forever, Until It Was No More: The Last Soviet Generation (Princeton: Princeton University Press, 2006). Other examples include Bruce Grant, In the Soviet House of Culture: A Century of Perestroikas (Princeton: Princeton University Press, 1995), and Douglas Rogers, The Old Faith and the Russian Land: A Historical Ethnography of Ethics in the Urals (Ithaca: Cornell University Press, 2009). Both books contain information on Brezhnev-era consolidations of rural settlements and their post-Soviet repercussions.

10. Yurchak, Everything was Forever, 36.

11. Anne Gorsuch and Diane Koenker, eds., The Socialist Sixties: Crossing Borders in the Second World (Bloomington: Indiana University Press, 2013). For a volume that brings together historians and anthropologists in their view of life under Brezhnev and his immediate 
Recognizing such dangers of genealogical approaches, archival research on the recent past can be usefully motivated by links which "witnesses of the times" (German Zeitzeugen) establish between then and now. For example, the journal editor's claim that the openness of her youth somehow explains her current religious engagement can give rise to a number of questions for deeper probing into written and oral sources. What exactly was Brezhnev-era society open to? What was it about this openness that enabled some members of the last Soviet generation to later become engaged in religious work? Since the journal editor was not alone among post-Soviet churchgoers in describing her religious involvement as something quite recent and initially difficult, I assume that what they picked up in their youth were not religious inclinations, but an array of skills and values with no overt theological content that helped involvement in a faith community make sense later in life. Rather than being a continuation of a religious turn that started under Brezhnev, I see post-Soviet religiosity among members of the last Soviet generation as one possible response to a key contradiction of the Brezhnev era that can be traced in archival documents as well as oral testimonies: the contradiction between a continuing rhetorical commitment to growth and change and increasingly rigid structures of bureaucratic control.

\section{The question of late Soviet religious revival}

The emerging historical scholarship on the Brezhnev era confirms my interlocutor's sense that much more went on during the years between 1964 and 1982 than is suggested by the label of "stagnation." Although Brezhnev replaced the utopian promises of Khrushchev's rule with a more bureaucratic approach to leadership that emphasized stability and predictability for bureaucratic elites as well as for those governed by them, ${ }^{12}$ many areas of cultural life remained in flux even after the crackdown against the Prague spring in 1968. The work of the filmmaker Andrei Arsen'evich Tarkovskii (1932-1986), whose film about the fifteenth-century monk and icon painter Andrei Rublëv was shot in 1965 and released in a cut version in 1971 is an example of the possibilities as well as the limits of cultural creativity during those years. ${ }^{13}$

Tarkovskii's success in representing Russian Orthodox Christianity as an integral part of Russia's historical identity, and an icon painter as an archetype of the modern artist, resonated with a number of other cultural trends of the late 1960s and 70s that indicated an increased interest in the pre-Soviet past and in the

successors, see Neringa Klumbyte and Gulnaz Sharafutdinova, eds., Soviet Society in the Era of Late Socialism, 1964-1985 (Lanham: Lexington Books, 2013).

12. George Breslauer, Khrushchev and Brezhnev as Leaders: Building Authority in Soviet Politics (London: George Allen \& Unwin, 1982); Jerry F. Hough and Merle Fainsod, How the Soviet Union is Governed (Cambridge: Harvard University Press, 1979), chapter 7.

13. Nariman Skakov, The Cinema of Tarkovsky: Labyrinths of Space and Time (London: Tauris, 2012). 
construction of national roots. The documentation and preservation of archeological sites and architectural monuments became a concern for youth groups and local history clubs, the so-called "village prose" writers mourned the destruction of rural communities through urbanization and environmental degradation, and movements of hikers and mountaineers discovered some of the same rural spaces anew. ${ }^{14}$

In official cultural policy, Russians began to receive attention as an ethnic group with its own cultural traditions. The Khrushchev-era campaign for "new traditions" led to a more focused attempt starting in 1965 to promote secularized versions of popular festivals, which came to include such Russian folk celebrations (cleansed of their Christian content) as "farewell to the Russian winter" (maslennitsa) and "birch tree" (berëzka, taking up themes of Pentecost), and the press discussed Russian peasant culture with increasing frequency. ${ }^{15}$ Contrasting with these more conservationist trends but equally indicative of ongoing shifts away from revolutionary Marxist Orthodoxy were developments toward greater attention to mass appeal in film production and theater, growing awareness of international fashion and consumer culture through film and television, and new fields of empirical sociology and ethnography that studied the social reality of Soviet citizens rather than looking at them through the predictions of evolutionist schemes of historical development. ${ }^{16}$ As probably the economically most prosperous period in the history of the Soviet Union, the 1970s offered ample opportunity for people to engage their activities and imaginations outside of the frameworks narrowly defined by Communist Party and trade union organizations.

Some scholars argue that these trends toward an interest in areas of life not immediately sanctioned by official ideology translated into a widespread turn to religion as the ultimate haven of national traditions and non-Marxist ideology. There are indeed convincing indications for some increase in religious activity during the later years of the Brezhnev era. Drawing on a mix of archival documents and oral

14. Emily Johnson, How Saint Petersburg Learned to Study Itself: The Russian Idea of Kraevedenie (University Park: Pennsylvania State University Press, 2006); Kathleen Parthé, Russian Village Prose: The Radiant Past (Princeton: Princeton University Press, 1992); Jeremy Morris, "From Chudak to Mudak? Village Prose and the Absurdist Ethics of Evgenii Popov," Modern Language Review, 99, 3 (2004): 696-710.

15. Anonymous, "Sotsiologicheskoe pereustroistvo byta i bor'ba za novye traditsii [The sociological transformation of life and the struggle for new traditions]," lecture script for discussion in the atheist section of the Knowledge Society, 1963, Copy on file in the Russian State Library, Moscow; Iurii V. Arutiunian et al., Russkie: etnosotsiologicheskie ocherki [The Russians: ethnosociological essays] (M.: Nauka, 1992), 392; Margaret Paxson, Solovyovo: The Story of Memory in a Russian Village (Bloomington: Indiana University Press, 2005), 335-336.

16. Joshua First, "From Spectator to Differentiated Consumer: Film Audience Research in the Era of Developed Socialism (1965-80)," Kritika, 9, 2 (2008): 317-344; Susan Costanzo, "Reclaiming the Stage: Amateur Theater-Studio Audiences in the Late Soviet Era," Slavic Review, 57, 2 (1998): 398-424; Ol'ga Gurova, Sovetskoe nizhnee bel'e: mezhdu ideologiei i povsednevnost'iu [Soviet underwear: between ideology and the everyday] (M.: Novoe Literaturnoe Obozrenie, 2008), 125-134; Vladimir Shlapentokh, The Politics of Sociology in the Soviet Union (Boulder: Westview, 1987); Iulian Bromlei, Etnos i etnografiia [Ethnos and ethnography] (M.: Nauka, 1973). 
histories from members of the intelligentsia in the Ukrainian SSR, Viktor Yelensky concludes that by the mid-1970s, control over the activity of religious organizations had relaxed and religious institutions as well as informal esoteric circles attracted young members. ${ }^{17}$ Judith Deutsch Kornblatt documents the experience of ethnic Jews who became Russian Orthodox Christians in the 1960s and remained active in the 1970s, most famously in the circle around the priest Aleksandr Men'. Protestant dissenters drew the attention of their western contemporaries from the mid-1960s onward..$^{18}$

Drawing on oral histories with members of the administrative and political apparatus of the Communist Party in Moscow and other members of the political and academic elite, Nikolai Mitrokhin likewise emphasizes the religious leanings which many of his interviewees cultivated during their youth. He suggests that spiritual searching in reaction to urbanization and secularization paralleled the contemporaneous spread of new religious movements among young people in Western Europe and North America. In a somewhat softer version of the same narrative, John and Carol Garrard argue that the increased interest in national heritage evident throughout the Brezhnev era prepared the way for the upsurge of interest in Russian Orthodox Christianity that occurred during the celebrations of the millennium of the baptism of the Kievan Rus' in $1988 .{ }^{19}$ Sergei Zhuk, based on evidence from eastern Ukraine, points to the way in which school field trips taken in the name of patriotism and interest in cultural heritage exposed young people to ideas that were outside the framework of Soviet ideology, including religious traditions. Looking at Soviet Central Asia, Adeeb Khalid sees Islam turning into an important aspect of national heritage after Stalin's death, through the secularization of ethnic celebrations and traditions, but also through the emergence of unofficial circles of students around ulama (religious scholars).$^{20}$

Focusing on different religious traditions, these scholars describe the Brezhnev-era Soviet Union as a world that was diverse in ideology and lifestyle.

17. Viktor Yelensky, "The Revival before the Revival: Popular and Institutionalized Religion in Ukraine on the Eve of the Collapse of Communism," in Catherine Wanner, ed., State Secularism and Lived Religion in Soviet Russia and Ukraine (New York: Oxford University Press, 2012), 302-330.

18. Judith Deutsch Kornblatt, Doubly Chosen: Jewish Identity, the Soviet Intelligentsia, and the Russian Orthodox Church (Madison: University of Wisconsin Press, 2004); Michael Bourdeaux, Religious Ferment in the Soviet Union: Protestant Opposition to Soviet Religious Policy (London: Macmillan, 1968).

19. Nikolai Mitrokhin, "Peredacha, institutionalizatsiia i chastichnaia kommertsializatsiia religioznykh praktik v srede sovetskoi intelligentsii vo vtoroi polovine $1950 \mathrm{kh}$ - pervoi polovine 1980kh godov [The transmission, institutionalization, and partial commercialization of religious practices among the Soviet intelligentsia from the late 1950s to the early 1980s]," Paper delivered at the conference "Lived Religion in the USSR: Survival and Resistance under Forced Secularization," Russian State Humanities University, February 16, 2012; John and Carol Garrard, Russian Orthodoxy Resurgent: Faith and Power in the New Russia (Princeton: Princeton University Press, 2008).

20. Sergei Zhuk, "Religion, Westernization, and Youth in the 'Closed City' of Soviet Ukraine, 1964-84," Russian Review, 67, 4 (2008): 661-679; Adeeb Khalid, Islam after Communism: Religion and Politics in Central Asia (Berkeley/L.A.: University of California Press, 2007), 112-114. 
They are sensitive to the methodological problem of sharply dividing the post-Soviet era (as a time of religious revival) from the Soviet era (as a time of atheism and religious repression), when the biographies of several generations of Soviet citizens stretch across both periods. However, their sources are limited either to the memories of members of urban, highly educated elites or to materials from the Ukrainian SSR. The latter may present an untypical case, since the western parts of the republic became part of the Soviet Union after the Second World War, when the worst physical persecution of religious believers had ceased. The Ukrainian population thus had unusually high levels of exposure to lived religious practice throughout the postwar era. ${ }^{21}$

Another source of claims for a Brezhnev-era religious revival are reports by Soviet officials that warn of high levels of religious activity. These are not new to the 1970s, but recur periodically throughout the 1950s and 60s. In the Volga region, increases in donations to churches and mosques were reported at least since the early 1960s and continue into the 1970s. Officials explain the increases by reference to the rising levels of prosperity of Soviet citizens. ${ }^{22}$ Bureaucratic reports on high levels of engagement with religious rituals are usually linked to calls to combat unregistered religiosity ${ }^{23}$ or to supervise existing organizations more strictly. ${ }^{24}$ It is thus hard to tell if such reports reflect actual increases in religiosity, or rather the rhythms of Soviet political campaigns, where times of heightened attention to religiosity alternated with periods when other issues were higher on the agenda. ${ }^{25}$

21. Catherine Wanner, Communities of the Converted: Ukrainians and Global Evangelism (Ithaca: Cornell University Press, 2007).

22. NART (Natsional'nyi arkhiv respubliki Tatarstan - National Archive of the Republic of Tatarstan), f. R-873, Commissioner for Religious Affairs, op. 1, d. 11, 1. 110-111, Report on the work of the commissioner of religious cult affairs for the Tatar ASSR, April 1963; GARF (Gosudarstvennyi arkhiv Rossiiskoi Federatsii - State Archive of the Russian Federation), f. R-6991, Council of Religious Affairs, op. 6., d. 634, 1. 100, Report from the commissioner of religious affairs for the Mari ASSR, October 21, 1974.

23. GARF, f. R-6991, op. 3, d. 571, 1. 134, Report of Commissioner Nabatov on religious life in the Mari ASSR, October 12, 1950; GARF, f. 6991, op. 4, d. 308, Simultaneous count of religious organizations on January 1, 1962, Materials from the Mari ASSR; NART, f. R-873, op. 1, d. 13, 1. 60-61, Circular from the Council of Ministers of the Tatar ASSR to District and Town Executive Committees reporting on the results of the simultaneous count in the Tat ASSR, June 19, 1962.

24. NART, f. R-873, op. 1, d. 11, 1. 6-8, Report on carrying out the Council of Ministers resolution of March 16, 1961, "On strengthening the control over enforcement of laws on religious cults," Commissioner Mangutkin, n.d.

25. For attempts to periodicize these campaigns in earlier decades of Soviet history, see Tatiana Chumachenko, Church and State in Soviet Russia: Russian Orthodoxy from World War II to the Khrushchev Years (Armonk: Sharpe, 2002, transl. Edward Roslof); Mikhail Shkarovskii, Russkaia Pravoslavnaia Tserkov' $v X X$ veke [The Russian Orthodox Church in the twentieth century] (M.: Lepta, 2010). On the problem of a possible overemphasis on religious practices in Soviet reports, see Sonja Luehrmann (Sonia Liurmann), "Chto my mozhem znat' o sovetskoi religioznosti? Sopostavlenie arkhivnykh i ustnykh istochnikov iz poslevoennogo Povolzh'ia [What can we know about Soviet-era religiosity? Juxtaposing archival and oral sources from the post-war Volga region]," Gosudarstvo, Religiia, Tserkov' v Rossii i za rubezhom 30, 3-4 (2012): 485-504. 
During the Brezhnev era, a first peak of attention to anti-religious work occurred in 1965, when there was a concerted effort to organize and promote new Soviet holidays and life-cycle rituals that had been invented in the 1920s and 1950s. This happened amidst rising concerns about dissenting groups that had split off from larger Christian churches.$^{26}$ A second peak occurred in 1972/73, when the focus was on reorganizing state propaganda efforts to make them more politically and economically effective. ${ }^{27}$ It would thus be inaccurate to say that the state gave up on atheist work under Brezhnev, although the rising complaints about the "religious indifference" of young people indicate that it became difficult to convince the population that religion continued to be harmful and dangerous under established socialism..$^{28}$

One of these empirical studies with a broad geographical base presents no clear picture of steep increases in religiosity either, although its results did not please supporters of atheism. Surveys conducted by Moscow sociologists among ethnic Russians in four Soviet cities in 1970 and 1980 showed that declared religiosity rose slightly, but not dramatically across this decade. In Saratov, 12.2 percent of those surveyed in 1970 called themselves religious believers or wavering between belief and unbelief, and their number rose to 13.4 percent in 1980. Among ethnic Russians in Tashkent, percentages rose from 15 to 17.5 percent, in Kishinëv from 10.2 to 14.3 percent. Ethnic Russians in the Georgian capital of Tbilisi, among whom self-reported religiosity was highest in 1970, also experienced the sharpest rise, from 25 to 34.3 percent. During the same period, the reported observance of Christian holidays such as Christmas or Easter was higher than reported belief, and rose much more steeply: in Kishinëv they almost doubled from 14.9 to 29.7 percent, while also rising from 27.2 to 34.2 percent in Saratov and from 22 to 28.5 percent in Tashkent. ${ }^{29}$

The authors of the study suggest that ethnic consciousness was on the rise more than religiosity, especially in cities where Russians lived together with members of other nationalities. Another interpretation could be that by 1980 , respondents perceived a lower risk in admitting to behavior that did not conform to Soviet ideological orthodoxy, a process of relaxation of ideological vigilance that is also

26. John Anderson, Religion, State and Politics in the Soviet Union and Successor States (Cambridge: Cambridge University Press, 1994) 69-74; Victoria Smolkin-Rothrock, "A Sacred Space is Never Empty: Soviet Atheism, 1954-1971," Ph.D. diss., University of California Berkeley, 2010; Elena Zhidkova, "Sovetskaia grazhdanskaia obriadnost' kak al'ternativa obriadnosti religioznoi [Soviet civil rituals as alternatives to religious rituals]," Gosudarstvo, Religiia, Tserkov' v Rossii i za rubezhom 30, 3-4 (2012): 407-428.

27. During those years, for example, radio shows in the Mari ASSR focused on religion and alcohol abuse, Communist Party organizations focused on reactivating atheist propaganda, and local newspapers published series of pages of atheist materials entitled "Atheist's page" (Mariiskaia Pravda, 1972) or "Page for believers and unbelievers" (Put' k kommunizmu, Medvedevo district, February to September 1973).

28. Evgenii Khlebnikov, Nekotorye voprosy formirovaniia ateisticheskoi ubezhdennosti [Some questions of the formation of atheist convictions] (Ioshkar-Ola: Mariiskoe knizhnoe izdatel'stvo, 1977) 13-14.

29. Arutiunian et al., Russkie, 330. 
reported by Yelensky for the Ukrainian SSR. ${ }^{30}$ But many respondents framed their behavior as not motivated by religious belief, indicating that the shift may have been toward a more positive valuation of ethnic customs and traditions, while religion remained ideologically suspect.

The combined evidence suggests that there was an increased interest in practices and traditions outside of Marxism-Leninism among cultural and political elites in urban centers, including, but not limited to, involvement in religion and spirituality. Along with this went a generational shift where young people who had come of age in the post-war Soviet Union, whose external borders and political-economic system were secure, were less receptive to calls for ideological vigilance. ${ }^{31}$ Although this trend may indeed have helped prepare future leaders of a broader religious revival starting in the final years of perestroika, the evidence should not be overinterpreted to the point where Brezhnev's Soviet Union appears to be a society in hidden religious turmoil. The Orthodox journal editor was just one of many post-Soviet religious activists whom I interviewed in the Volga region whose entry into religious practice had occurred late in life, after the collapse of the Soviet Union. The journal editor's misgivings about norms of dress, gender, and liturgical participation in the church show her continued struggle to reconcile the different value systems she was exposed to over her lifetime. Only her mother's death and Russian Orthodox burial about half a year before our interview had begun to soften her aversion, helping her to feel less self-conscious about participation in church ritual.

In a similar way, a Tatar factory worker who taught Quranic reading in the mosque and a Mari teacher who participated in traditional sacrificial rituals had taken up these practices after retirement age, when their mothers died and they became the oldest female member of their households, feeling responsibility for praying for dead ancestors and for the health and success of their children. ${ }^{32}$

What these interviewees brought from their late Soviet youths was less an ongoing religious commitment than an approach to acquiring new skills and knowledge. They did not take up religious practice as something natural, but systematically tried to acquire knowledge about it through reading books and listening to radio shows. The Tatar woman even took a correspondence course at the medrese (Islamic school) in Kazan, the capital of neighboring Tatarstan. Similar to the members of the last Soviet generation interviewed by Alexei Yurchak, these people had lived their youth and early adulthood in a political system whose stability they accepted as given and within whose parameters they learned to work. It was only after the unexpected disappearance of this political system that they discovered that many

30. Yelensky, "Revival before the Revival," 318.

31. Juliane Fürst, Stalin's Last Generation: Soviet Post-War Youth and the Emergence of Late Socialism (New York: Oxford University Press, 2010); Diane Koenker, Anne Gorsuch, "Introduction: The Socialist 1960s in Global Perspective," in Koenker, Gorsuch, eds, The Socialist Sixties, 1-21.

32. Luehrmann, Secularism Soviet Style, 208-209. These women were born in 1942 and 1945, respectively. 
of their skills could be put to new uses in the service of new ideological purposes. Given that some former Komsomol organizers and trade union secretaries became entrepreneurs while others became religious activists, ${ }^{33}$ each group benefiting from skills of "working with people" that they acquired in Soviet ideological work, ${ }^{34}$ it seems to make less sense to look for a direct link between post-Soviet religiosity and Brezhnev-era religious searches. Rather, one could ask what skills, habits, and expectations people brought from their Brezhnev-era youths that could be recycled for ideologically unintended uses, and what internal contradictions existed within the ideals and lived experiences of that "surprisingly open" time that may have predisposed some people to look to religion for answers later, when the opportunity presented itself through a changed political climate and their own changing position in the succession of generations.

\section{Late socialism in memory and in the archives}

Other interviewees also framed their religious involvement as distinctly post-Soviet, while tracing the skills and self-expectations that made them effective participants in religious work to the late Soviet era. A biologist involved in training Orthodox Christian women as Sisters of Mercy said that it was easy to recruit doctors to give these laywomen basic paramedical training, because Soviet physicians had all participated in initiatives to educate the broader public about medicine and spread scientific ways of looking at the world. As a biologist, she had been part of the same networks of popular education, organized through the Communist Party's department of propaganda and agitation and through the Knowledge Society (Obshchestvo Znanie). ${ }^{35}$

These networks of lectures and workplace-based study circles had had their first post-war blossoming under Khrushchev and were initially curtailed after Brezhnev took over, as part of his efforts to impose greater bureaucratic control on spheres that had been left to a certain degree of self-direction during the Thaw. Networks of political education were soon permitted to grow again, but with a more regulated

33. Alexei Yurchak, "Entrepreneurial Governmentality in Postsocialist Russia: A Cultural Investigation of Business Practices," in Victoria Bonnell and T. Gold, eds., The New Entrepreneurs of Europe and Asia (New York: Sharpe, 2002), 278-324; Luehrmann, "Recycling Cultural Construction."

34. Douglas Rogers, "Old Belief between 'Society' and 'Culture': Remaking Moral Communities and Inequalities on a Former State Farm," in Mark Steinberg and Catherine Wanner, eds., Religion, Morality, and Community in Post-Soviet Societies (Bloomington: Indiana University Press, 2008), 115-147.

35. The Knowledge Society was founded in 1947, with a mandate to spread knowledge about Soviet political as well as scientific developments. See David Powell, Antireligious Propaganda in the Soviet Union: A Study of Mass Persuasion (Cambridge, MA: MIT Press, 1975) and Luehrmann, Secularism Soviet Style. On the Society's predecessors in popularizing Soviet science, see James T. Andrews, Science for the Masses: The Bolshevik State, Public Science, and the Popular Imagination in Soviet Russia, 1917-1934 (College Station: Texas A \& M University Press, 2003). 
curriculum and more emphasis on monitoring educational outcomes. ${ }^{36}$ Post-Soviet doctors with experience in "taking knowledge to the people," as the motto of the Knowledge Society was, would have acquired these skills in the late Soviet system of adult education. It was these skills, rather than any prior religious dispositions, that they put to work in the interest of the church.

A retired childcare worker leading a Baptist Bible study (born 1949) remembered her work as the propagandist of her work collective as a source of skills for adapting content to different audiences and showing how it connected to their lives. She kept photographs showing how she had traveled around the Volga region and to Moscow for seminars. "God, I didn't know you yet, but you were leading me already," was her commentary when looking at the pictures, but also, more remorsefully, "Lord, forgive me for all the foolishness (bezobrazie)." She had thought she would never travel again after the collapse of the Soviet Union, but now had renewed opportunities to do so through Baptist organizations.

A Mari writer who served as a Lutheran deacon (born 1955) treated his past as a Komsomol official with equal ambivalence: it was a source of skill and useful connections, but also led people to question his sincerity when he visited villages on mission trips, since they remembered that "he used to talk about completely different things." He himself insisted he had really always talked "about the same thing, about goodness."

All these people entered into religious practice at a time when their secular careers had come to an end through the collapse of the Soviet Union and their approaching retirement age. This change in national and personal life also meant an end of movement: no more seminars organized by the party or trade union, no more travels to villages for lectures and employment. When recalling the Soviet period, they all had quite positive memories, calling themselves convinced communists who were active in the Komsomol or the Communist Party. They also shared a kind of folk periodization of the Soviet period that I encountered in many conversations with people in Russia: life was good and economically secure until "Gorbachev" or "perestroika" came along and destroyed everything. From the hindsight of the early 2000s, the relative prosperity of the 1970s has come to define the Soviet Union for many who lived through its collapse (rather than, for example, the Stalin era). What defines the Brezhnev era in these memories is not "stagnation," but relative material well-being, security, and opportunities to move around within the space of the Soviet Union. ${ }^{37}$

However, the same people also remembered the hardship of doing ideological work, the constant struggle against lack of interest among members of their audience. The Baptist study leader contrasted the ease of spreading the word of God

36. David Wedgwood Benn, Persuasion and Soviet Politics (Oxford: Basil Blackwell, 1989), 138-140.

37. Alaina Lemon, "Sympathy for the Weary State?: Cold War Chronotopes and Moscow Others," Comparative Studies in Society and History, 51, 4 (2009): 832-864; Gorsuch and Koenker, The Socialist Sixties. 
to the difficulty of getting people to listen to a lecture on the works of Lenin, which was only possible by promising them a dance afterwards. A rural sports teacher who had served as party secretary in his village since the late 1970s remembered that no one liked going door-to-door with political agitation: "People are tired, they are coming in after milking their cows, and here you come talking to them about politics." For post-Soviet religious activists, contrasting the ease with which they spread stories about God to the difficulty of spreading Marxism-Leninism was a way of emphasizing the independent agency of God's word. It is also a reflection on Brezhnev-era ideological work, and the contradiction between the effort and imagination it required from those who conducted it and the boredom and distraction with which audiences received its familiar messages. The contradiction is that between a society whose central forms were based on the need to mobilize for the future, while the citizens and those who governed them appeared more interested in stability. In personal memory, this contradiction appears in affirmations of being excited and committed to ideological work while finding it very difficult to achieve broad participation. In the archives, the specific characteristics of Brezhnev-era ideas about change and progress become most apparent when comparing them to the Khrushchev-era campaigns they were designed to replace.

Consider, for instance, the contrast between a campaign for public order in 1960 and ideas about orderly transformations that survived into the 1970s. In 1960, the plenum of the Ioshkar-Ola city committee of the Communist Party discussed measures taken to fulfill the March 1959 Central Committee resolution "On the participation of toilers in maintaining public order in the country." 38 The aim was broad popular participation in the campaign, and the indicators for success were equally broad: membership in the newly established people's patrols (narodnye druzhiny) and comrade's courts counted as a sign of popular engagement, but so did participation in sports, amateur arts, and other presumably orderly ways of spending ones free time. Proposed measures to improve the prevailing shortcomings in public support for order included:

Regularly carry out lectures, conversations, talks, discussions, and thematic and literary evenings for industrial and service workers. Involve more toilers in amateur arts and sports, organize hiking trips, tours, and other mass events. Improve the work with the population in clubs, red corners, libraries, agitational points. Further develop the activities of universities of culture. ${ }^{39}$

The ideal orderly society here is one in which individuals are engaged in public life in a variety of ways that are all assumed to serve the same ideological aims, but

38. On the context of this resolution, see Brian LaPierre, Hooligans in Khrushchev's Russia: Defining, Policing and Producing Deviance During the Thaw (Madison: University of Wisconsin Press, 2012), chapter 4.

39. GARME (Gosudarstvennyi arkhiv respubliki Marii El - State Archive of the Republic of Marii El), f. P-8, city committee of the Communist Party, Ioshkar-Ola, op. 7, d. 480, 1. 9, Resolution of the fifth plenum of the Ioshkar-Ola city committee, September 20, 1960. 
are very different in form and content. A hike in the mountains can equally serve public order as listening to a lecture or attending evening and weekend courses at a "university of culture." All these activities are treated as ends in themselves; participation in them is already proof of the result they are intended to achieve an engaged, mobilized society. Rather than being measured by external results, active engagement and ideological growth was supposed to manifest itself through sheer numbers of offerings and participants. ${ }^{40}$

In the Brezhnev era, study remained important, but it was no longer an end in itself. Fitting in with a rising interest in what one might call "audience research" - documenting and evaluating the effects of cultural and political events on participants ${ }^{41}$ - there seems to have been greater pressure on those conducting political study to produce evidence of its wider effects. Those effects that were easiest to document and most likely to impress superiors were increases in labor productivity, although the causal connection between study and productive labor often remained vague. In 1974, for example, instructors involved in political and economic education in a rural district of the Mari ASSR met for a conference where they discussed "the influence of different forms of education on the strengthening of labor activity." The engaged participation of the collective farm workers in their study circles through "independent work [...] with political literature," discussions and presentations is still stressed, but it is now called "the method of activation," and rhetorically linked to raising levels of "labor and political activity." The report ends by praising the economic successes of the State Farm "New Life":

These can be explained by reference to the correct preparation, organization, and carrying out of courses in the schools of communist work with the livestock keepers $[\ldots]$. Constant attention to the retention of economic knowledge, study and dissemination of progressive experience, raising the level of political knowledge and of culture - all of this has a positive effect on the results of the productive activities of the whole farm. ${ }^{42}$

Participation and mobilization is no longer a good thing in and of itself, but is evaluated in terms of its economic results, as indicated in the shift toward "political and economic study" as an umbrella term for efforts of adult education. This can be read as a repudiation of Khrushchev's hopes for a mobilized society where political study would translate directly into civic-mindedness and a concern for the common good. It fits with political analyses of the Brezhnev-era Soviet

40. This emphasis on "active participation" also manifested itself in evaluations of study circles. GARME, f. P-8, op. 7, d. 506, Reports on the results of check-ups on educational work, February 2 to March 24, 1960,1. 105-105v.

41. Benn, Persuasion and Soviet Politics, 138-140; First, "From Spectator to Differentiated Consumer."

42. GARME, f. P-14, Novyi Tor"ial district committee of the Communist Party, op. 27, d. 10, 1.35-36, Information on the state of political and economic study in Novyi Tor" ial district in the 1973-1974 academic year, May 31, 1974. 
Union as one that emphasized bureaucratic control over trust in spontaneous mass activity, ${ }^{43}$ and also with Alexei Yurchak's account of the "citational temporality," ${ }^{4}$ in which familiar tropes such as independent work, new methods, and self-activity remained operational even in a political system that would have been very uncomfortable with their literal implications. However, by constantly citing tropes of mobilization, newness, and personal development, Brezhnev-era discourse also preserved internal contradictions that undermined the aim of stability. The discourse of "spiritual development" is especially important for understanding how Brezhnev era social dynamics could help prepare the way for post-Soviet religious revival while remaining oriented to the secular spheres of human labor and interpersonal relations.

\section{The spirit of late socialism}

Scholarship on perestroika has noted the frequency with which Mikhail Gorbachev referred to "spirituality" (dukhovnost) and called for renewed attention to spiritual aspects of communist construction..$^{45}$ A connection that is less commonly made is that to the term "spiritual values" (dukhovnye tsennosti) that was an important concern in Khrushchev and Brezhnev-era campaigns against drinking, petty theft, and vandalism and for cultured life. ${ }^{46}$ In these older Soviet usages, "spiritual" is not analogous to "religious" or "supernatural." Rather, it refers to the sphere of ideas, human personality, and interpersonal relations, as opposed to the "material" sphere of physical labor and relations of production that Orthodox Marxism described. Through its roots in Hegelian philosophy, talk about spirit was associated with the ideas of growth and change that were characteristic of late Soviet systems of education.

Khrushchev-era appeals to spiritual values and spiritual development came with a theoretical claim about the importance of personal experience and meaning-making for the transition from socialism to communism. A major collaborative study conducted by the Institute of Philosophy of the Soviet Academy of Sciences and the Knowledge Society in the early 1960s (and published after Khrushchev's removal from office) included empirical materials from twenty-five Soviet factories to illuminate the "spiritual world" of workers in the transition from socialism to communism, a goal that the 1961 Communist Party program declared to be within

43. Breslauer, Khrushchev and Brezhnev as Leaders.

44. Yurchak, Everything was Forever, 61-63.

45. Riita Pittman, "Perestroika and Soviet Cultural Politics: The Case of the Major Literary Journals," Soviet Studies, 42, 1 (1990): 111-132; Mark Sandle, "The Final Word: The Draft Party Programme of July/August 1991,” Europe-Asia Studies, 48, 7 (1996): 1131-1150.

46. Natasha Kolchevska, "Angels in the Home and at Work: Russian Women in the Khrushchev Years," Women's Studies Quarterly, 33, 3-4 (2005): 114-137, esp. 123; Susan Reid, "Cold War in the Kitchen: Gender and the De-Stalinization of Consumer Taste in the Soviet Union under Khrushchev," Slavic Review, 61, 2 (2002): 211-252, esp. 225 n. 53. 
reach of a single generation. ${ }^{47}$ At a conference devoted to the book project, managing editor Tsolak Aleksandrovich Stepanian explained that during the transition from socialism to communism, consciousness no longer merely reflected being, but could advance ahead of it. For instance, progressive workers in socialist society could already have a "communist" consciousness, while productive relations were still at the socialist stage. Stepanian proclaimed that the most pressing social task was "the all-round development of personality" 48 - another term often associated with perestroika that has deeper Soviet roots. ${ }^{49}$

The fact that this study was published in 1966 show that the language of spiritual values retained currency under Brezhnev, even as hopes of the imminent onset of communism faded. While it certainly stands in contradiction with orthodox forms of Marxism, this language of spirituality should not be taken as a residual form of "invisible religion," ${ }^{50}$ much less an expression of religious revival. In the works of Soviet sociologists, "spirituality" was an antidote to religion. By developing spiritual capacities, people diminished the hold of religious traditions on their lives. In the Mari ASSR, the sociologist Viktor Stepanovich Solov'ev wrote that the growth of "spiritual needs" (dukhovnye potrebnosti) of Soviet citizens was an opportunity to decrease their interest in religion, whereas state failures to provide cultural and spiritual sustenance held underserved populations back in harmful traditions. "It is not enough to liberate a person from the captivity of religious ideas, it is necessary to provide for his all-round spiritual development," as Solov'ev wrote in a study of atheism and religiosity in the Mari ASSR..$^{51}$

In Solov'ev's statistics, such "spiritual development" was measured mainly in terms of participation in a humanistic culture of reading books, attending cinema sessions, and striving to enlarge one's circle of friends and acquaintances. ${ }^{52}$ Religious activity, argued these sociologists, was strong in those parts of the predominantly rural republic where clubs and other social services were either lacking or failed to offer programming for housewives and the elderly, two

47. Tsolak Aleksandrovich Stepanian, ed., Stroitel'stvo kommunizma i dukhovnyi mir cheloveka [Communist construction and the spiritual world of the human being] (M.: Nauka, 1966).

48. GARF, f. R-9547, All-Union Knowledge Society, op. 1, d. 1314, 1. 34, Stenograph of the scholarly conference "Laws of the formation and development of the spiritual life of communist society," May 9-11, 1963.

49. J. Sutherland, "Perestroika in the Soviet General School: From Innovation to Independence?" in J. Dunstan, ed., Soviet Education under Perestroika (London: Routledge, 1992), 14-29.

50. Thomas Luckmann, Die unsichtbare Religion [Invisible religion] (Frankfurt: Suhrkamp, 1991).

51. Viktor Solov'ev, Sotsiologicheskie issledovaniia - v praktiku ideologicheskoi raboty: Nekotorye itogi izucheniia problem byta, kul'tury, traditsii $i$ verovanii naseleniia Mariiskoi ASSR [Sociological research in the service of ideological work: Some conclusions from the study of problems of everyday life, culture, traditions and beliefs of the population of the Mari ASSR], Ioshkar-Ola: Mariiskoe knizhnoe izdatel'stvo, 1977, p. 110. For more on Solov'ev's work, see Luehrmann, Secularism Soviet Style, 54-60.

52. Solov'ev, Sotsiologicheskie issledovaniia, 100; Luehrmann, “A Multireligious Region in an Atheist State: Unionwide Policies Meet Communal Distinctions in the Postwar Mari Republic," in Wanner, ed., State Secularism and Lived Religion, 272-301, esp. 291-295. 
categories of people who were not well integrated into Soviet collectives and thus considered to be at particular risk of turning to churches, mosques, and sacred groves. A study conducted among Russian Orthodox Mari villagers in 1967/68 quoted a 73-year-old collective farm worker:

Why we go to church? I'll tell you why. Where else should we old women go? Go to the club - the young people laugh at us there: "Where are you going, granny? Decided to dance?" And for our brother[s], the old men, nothing goes on at the club either. Either they reel off a film, or organize a dance. We don't always have money to go see a film. And to church you can go without money. ${ }^{53}$

While trying to claim the label "spiritual" for secular Soviet culture alone, Brezhnev-era scholars and cultural workers also perceived a competition between Soviet and religious institutions in providing for beauty, edification, and companionship, as shown by the renewed emphasis on secular rituals starting in 1965 and by debates in atheist journals such as Nauka i Religiia. ${ }^{54}$ But beating churches at their own game was sufficient. In the context of a greater emphasis on measureable outcomes, cultural institutions had to stress the economic benefits of spiritual development. Just as the effectiveness of political education was measured by increases in labor productivity, the ideal outcome of spiritual and moral development became a person who had excellent work ethics while also appreciating classical music and literature. In the logic of official reports, spiritual values, cultured leisure, and a diligent attitude to work amounted to the same thing. For example, a 1973 report on political study in the rural Mari ASSR quoted from a discussion in a workplace study circle where retail staff had discussed ways to raise their labor productivity. A participant noted that "customers in our country spend about thirty billion hours shopping." Based on such facts, "participants became keenly aware of the importance of raising labor productivity in retail, [noting] that shortening the time spent on purchasing goods is of great significance for the spiritual growth (dukhovnogo rosta) of our workers." 55

Religious activity stood in contrast to spiritual growth because it destroyed labor productivity. A newspaper article about a drunk driving accident on St. Elijah's day (August 2), a day of commemoration of dead ancestors in many villages of the Mari ASSR, first proclaims that "religion and drunkenness are inextricably linked," and then itself goes on to construct a chain of consequences leading from the

53. Nikolai Sergeevich Sofronov, Ateisticheskoe vospitanie kolkhoznogo krest'ianstva [Atheist education for collective farm workers] (Ioshkar-Ola: Mariiskoe knizhnoe izdatel'stvo, 1973), 27.

54. Smolkin-Rothrock, "A Sacred Place is Never Empty"; "Problema 'obyknovennoi' sovetskoi smerti: Material'noe i dukhovnoe v ateisticheskoi kosmologii [The problem of 'ordinary' Soviet death: The material and the spiritual in atheist cosmology]," Gosudarstvo, religiia, tserkov' $v$ Rossii i za rubezhom, 30, 3-4 (2012): 429-462.

55. GARME, f. P-14, op. 26, d. 11, 1. 64-71, Information on the results of the academic year in the network of Party political education in Novyi Tor"'ial District, June 1, 1973. 
physical to the economic and emotional: "Where there are religious holidays, there is drunkenness, hooliganism, deadly injuries, and as a result harm to the people's economy, suffering to the family, and moral degeneration of the personality." 56 The choice to follow these paths of religious degradation becomes all the harder to understand because Soviet public life is all about providing alternative ways to development: "In our country everything is done for the fullest harmonic development of the human being. For this we have Sports Palaces, theaters, cinemas, hiking trips and other events." ${ }^{57}$

Again, the language of personal development is tightly linked to the economic wellbeing of the country, but opposed to religion, which is connected to stasis and degradation. The ideal Soviet person that emerges from this equation of spiritual and material growth is exemplified in an article about Anatolii Amel'chenko, a rural club director who manages to entertain his audience and realize his own "creative plans" by making films about local cultural traditions and exemplary workers, while impressing others with his diligence and reliability. The young cultural worker's dreams of a camera come true when his agitbrigade wins first prize in a district competition, and superiors trust him because of the results he delivers. "You, Amel'chenko, [...] are persistent not just in words, but in deeds. It's a pleasure to help you," says the collective farm chairman. In his lectures Amel'chenko always stresses the need to fulfill the economic obligations of the collective farm: "The more material goods we create, the better conditions will be for the further blossoming of culture, for people's spiritual growth." 58

\section{Flights of the spirit}

The figure of the exemplary lecturer and cultural worker Anatolii Amel'chenko illustrates the realities and limits of the remembered "openness" of the Brezhnev era. The article stresses creative work, which consists in documenting the economic successes of a collective farm, but also the openness of Soviet society to interethnic contacts and to its revolutionary and prerevolutionary heritage. Amel'chenko plans to make a film about a local Mari woman who married a Chuvash and moved to the neighboring republic of Chuvashia. His existing works document Mari dances and an excursion to the city of Ul'ianovsk, birthplace of Vladimir Lenin

56. N. Goriachev, "Rasplata za p'ianku v Il'in den' [Paying for drunkenness on St. Elijah's Day]," Put'k kommunizmu, August 25, 1973, 3.

57. Ibid. The link between religious traditions, alcohol, and uncultured and unhealthy behavior on the one hand and secular culture, health and wellbeing, and economic productivity on the other is consistently present in documents that deal with the struggle against religious holidays. See also GARME, f. P-14, op. 26, d. 7,1.115, Minutes of the district committee meetings of the CPSU, Novyi Tor"'ial, August 24, 1973.

58. S. Zakharov, "Chelovek, kotorogo zhdut [The eagerly awaited man]," Mariiskaia Pravda, October 27, 1972, 4 . 
and restored nineteenth-century town on the Volga. Amel'chenko's own spiritual growth starts when he returns to his native village after service in the army, ${ }^{59}$ and continues as he puts his creative talents and diligent determination in the service of his collective. This service is epitomized when he moderates a discussion about the farm's contribution to the unionwide festivities for the fiftieth anniversary of the USSR, celebrated in December 1972 and marked by special work obligations and premiums.

The article portrays the early 1970s as a time of optimism, in which different kinds of growth - in economic indicators, in creative possibilities, and in closeness between people - folded into one another quite easily. However, the equation between economic growth, intellectual development, and political usefulness could also become stifling, and here, I would propose, lie the internal contradictions that may have brought some of those who grew up in Brezhnev's Soviet Union to religious searching.

In European philosophical and religious traditions from St. Paul to Hegel, "spirit" is often a cipher for change, or more precisely, for the dynamic elements that propel collective and individual life forward. ${ }^{60}$ Brezhnev-era political discourse continued to promote change and the value of newness, while political practice emphasized stability. The resulting contradictions encouraged behavior that appealed to the norms of Soviet discourse while carving out spaces outside the framework of official politics. Several scholars working on this period have pointed to groups of people who "opted out" of the official framework without "resisting" socialism. These include radio enthusiasts, stiliagi, amateur actors, hikers, and historical restorers, as well as people who told political jokes with a subtle brand of cynicism. ${ }^{61}$ Many of these groups adopted some ideals of socialism - such as interest in technology or values of egalitarian access to culture - but used them for purposes of disengagement that subverted the monopoly of the Communist Party on citizens' energy and imagination. Science fiction literature has also been described as a genre that promoted socialist ideals of progress and change while enabling readers to dream of radical elsewheres.$^{62}$ What is common to all these fields of hobby and recreation is that they present places somewhat outside the political structures in which people could live out ideals of equality and transformation that were proclaimed in political rhetoric, but denied by the

59. On Brezhnev-era attempts to keep rural youths in their native regions, see Rogers, The Old Faith and the Russian Land, 136-137.

60. Dominic Boyer, Spirit and System: Media, Intellectuals, and the Dialectic in Modern German Culture (Chicago: University of Chicago Press, 2005).

61. Cathleen Giustino, Catherine Plum, and Alexander Vari, eds., Socialist Escapes: Breaking Away from Everyday Routine in Eastern Europe, 1945-1989 (New York: Berghahn, 2013); Peter Steiner, "Introduction: On Samizdat, Tamizdat, Magnitizdat and Other Strange Words that are Difficult to Pronounce," Poetics Today, 29, 4 (2008): 613-628; Alexei Yurchak, "The Cynical Reason of Late Socialism: Power, Pretense, and the Anekdot," Public Culture, 19, 2 (1997): 161-188.

62. Rustam Kats, Istoriia sovetskoi fantastiki [History of Soviet science fiction] ( $\mathrm{SPb}$.: Izdatel'stvo Sankt-Peterburgskogo universiteta, 2004). 
practice of "respect for personnel" that gave Brezhnev-era society its feeling of unchanging stability. ${ }^{63}$

Some high-profile religious figures of late Soviet and post-Soviet Russia come out of this milieu of deliberate disengagement from official politics, including liberal Russian Orthodox figures such as Alexander Men' and more conservative priests such as Father Dmitrii Smirnov ${ }^{64}$ As noted above, the provincial post-Soviet religious activists I interviewed tended to have a different, less oppositional trajectory. Coming out of cultural professions, their portrayals of themselves in the Soviet era resembled the club director Amel'chenko more than a disengaged dissident. What distinguished them from the stereotypical party cadre, however, was how seriously many of them claimed to have taken the calls for social engagement and spiritual growth to which they were routinely exposed. "I preferred to be a true communist outside the Party rather than a careerist within it," said the Tatar teacher of Quranic reading when she, gratefully in retrospect, recalled her refusal to join the Communist Party when invited to do so "because they needed more workers to join." As a trade union activist in charge of organizing amateur performances, she took the discourse of constant spiritual growth more literally than it was probably meant, and refused to equate it with the growth of her own career. At the same time, she clearly identified as having been not just a simple worker, but an "activist," and continued to apply the term obshchestvennaia rabota (social/volunteer work) to her current work at the mosque, begun in 1995. The Lutheran deacon and others expressed positive evaluations of Soviet initiatives of political education such as those of the Knowledge Society, pointing out that they brought crucial sources of information and entertainment to villages which were left to their own devices in post-Soviet austerity.

In Yurchak's terminology, these people portrayed themselves as having been among the "true believers" in communism whom normal people regarded with suspicion, much as many Russian citizens today regard people with too overt religious inclinations. In their recollections from post-Soviet hindsight, the spirit of late socialism tends to be understood positively in terms of mobility, dynamic connections between city and countryside, and possibilities of intellectual growth. Stasis enters into the picture in two ways: First with the collapse of the Soviet Union, when networks of training and mobility broke down. Second, in the idea that only a religious understanding of spiritual change truly allowed that change to continue over the whole life course and beyond, invalidating Soviet approaches to lifelong learning as illusionary.

63. Hough and Fainsod, How the Soviet Union is Governed, 253. For a vivid portrayal of this period in a North Caucasus republic from the point of view of a younger political cadre beginning his career in the middle of an old cohort of colleagues, see Georgi Derluguian, Bourdieu's Secret Admirer in the Caucasus: A World-System Biography (Chicago: University of Chicago Press, 2005).

64. Nikolai Mitrokhin, Russkaia Pravoslavnaia Tserkov': Sovremennoe sostoianie i aktual'nye problemy [The Russian Orthodox Church: Contemporary situation and current problems] (M.: Neprikosnovennyi zapas, 2004), 212. 
The Lutheran deacon described his youth as a time of easy upward movement through facilitating structures: a boarding school for gifted Mari youth and the Higher Party School in Moscow which he attended as the third and last member of his nationality. This movement came to a halt during late perestroika, when the position as a radio announcer to which he had been "sent" after his studies was cancelled, forcing him to wander between temporary jobs. In 1993, at age 38, he found himself in the hospital with heart problems, and encountered Christianity through another patient, who read the Bible and prayed. "I didn't know how to pray," he recalled, "I wasn't used to asking for anything."

\section{Conclusion: The Brezhnev era seen from downstream}

The initial difficulty of religious activity was a common theme of many interviews, as converts looked upstream from their post-Soviet to their Soviet life. The deacon's case shows perhaps most clearly that the process was not about abandoning one faith and choosing another, but accepting different norms of behavior and seeking out new sources of strength while retaining basic commitments to social service and personal development. In the Soviet Union of his youth, the budding Mari intellectual did not have to ask for anything because his path was determined by others who "sent" him places in the name of larger society. After a few years of stasis and stunted growth in the late 1980s and early 1990s, ideals of growth and change could again be realized in the context of religious institutions. But a precondition was acknowledging the limits of any secular schemes of advancement, locating agency outside of human individuals and collectives, and personally requesting help from that non-human source. The deacon's struggle to make the switch underlines the strangeness of religious activity to many members of the last Soviet generation. Their ability to adjust attests to the enduring habits of learning which were inculcated in them from an early age, anticipating some of the catch-phrases of perestroika. By continuing to promote lifelong learning during a time of stability, Brezhnev-era bureaucrats may have kept their society more open to new and competing influences than they ever intended.

Simon Fraser University

luehrmann@sfu.ca 